\title{
PENERAPAN ONTOLOGY WEB LANGUAGE PADA DOMAIN ULOS BATAK TOBA
}

\author{
Arnaldo Marulitua Sinaga ${ }^{1}$, Rini Juliana Sipahutar ${ }^{2}$, Dian Ira Putri Hutasoit ${ }^{3}$ \\ 1,2,3Fakultas Teknik Informatika dan Elektro, Institut Teknologi Del \\ Email: ${ }^{1}$ aldo@del.ac.id, ${ }^{2}$ rini.sipahutar@del.ac.id, ${ }^{3}$ dian.hutasoit@gmail.com
}

(Naskah masuk: 05 Juli 2018, diterima untuk diterbitkan: 25 Agustus 2018)

\begin{abstract}
Abstrak
Indonesia merupakan salah satu negara yang kaya akan keanekaragaman budaya. Setiap suku memiliki kekhasan masing-masing termasuk kekhasan dalam kain tradisional. Salah satunya adalah ulos, kain tradisional suku Batak Toba. Ulos merupakan simbol sakral dalam adat istiadat suku Batak Toba. Ulos terdiri dari berbagai macam jenis, motif, warna, makna hingga fungsi. Namun informasi mengenai ulos belum terdokumentasi dengan baik. Informasi ditransfer secara turun temurun yang memungkinkan informasi tersebut berubah dan bahkan hilang. Selain itu, beberapa sumber yang ada juga menyajikan informasi yang berbeda. Selanjutnya, ontologi bisa menjadi salah satu solusi untuk membantu mengelola informasi yang sudah ada supaya lebih terstruktur. Ontologi membantu memformalkan vocabulary yang ada pada domain ulos. Vocabulary itu kemudian dalam ontologi disebut sebagai konsep. Konsep tersebut saling berkaitan satu sama lain sehingga dapat dilihat sebagai suatu bentuk kesatuan (linked data) yang membentuk pola yang terstruktur. Kondisi ini yang kemudian mendukung pencarian dengan hasil yang bernilai semantik karena pola data yang disediakan saling berkaitan satu sama lain. Ontologi tersebut dapat direprentasikan menggunakan Web Ontology Language (OWL) yang merupakan vocabulary extension dari Resource Descriptive Framework (RDF). Kemudian untuk proses retrieving data diimplementasikan dengan menggunakan SPARQL.
\end{abstract}

Kata kunci: ulos, ontology, $O W L, R D F, S P A R Q L$,

\section{WEB ONTOLOGY LANGUAGE FOR ULOS BATAK TOBA}

\begin{abstract}
Indonesia is a very rich country in cultural diversity. Most of the ethnic groups have their own uniqueness including the peculiarities in traditional textiles. One of them is Ulos, traditional cloth of Batak Toba. Ulos is a sacred symbol in the Batak traditions. Ulos consists of various types, motifs, colors, meanings and functions. However, it is unfortunate that information of Ulos has not been well documented. This cultural heritage is welltransferred from generation to generation. The existing sources sometime provide different information. Therefore, ontology can be one solution to help manage existing information to be more well-organized. Ontology helps formalize all vocabularies on the Ulos domain. The vocabulary in the ontology is called as a concept. The concepts are related to each other so that it can be seen as a linked data that form a structured pattern. This feature supports information searching with semantic value. The ontology of Ulos Batak Toba has been developed by using Web Ontology Language (OWL), which is a vocabulary extension of the Resource Descriptive Framework $(R D F)$. Then for the data retrieving process we use SPARQL
\end{abstract}

Keywords: Ulos, ontology, OWL, RDF, SPARQL.

\section{PENDAHULUAN}

Indonesia negara dengan keragaman budaya yang memiliki lebih dari 250 suku bangsa asli (Dirjen Kebudayaan Indonesia, 2014). Hampir setiap suku memiliki bahasa, tradisi, bentuk rumah dan juga kain yang berbeda. Batak Toba merupakan salah satu suku di dataran tinggi Pulau Sumatera. Suku ini dikenal dengan "selimut" khasnya yang dinamakan Ulos. Ulos merupakan kain tradisional hasil tenun suku Batak yang secara harfiah diartikan sebagai sebuah selimut (Dirjen Kebudayaan Indonesia, 2014). Pada awalnya, ulos digunakan oleh nenek moyang suku Batak yang tinggal di daerah pegunungan untuk menghangatkan tubuh dan melindungi diri dari terpaan udara dingin. Namun seiring waktu, ulos kemudian digunakan juga sebagai simbol sakral 
dalam adat istiadat suku Batak yang ciri dan kegunaaanya berbeda dalam setiap rangkaian ritual adat istiadat (Muhammad, 2009; Niessen 2009). Kemudian penggunaan Ulos berkembang menjadi lambang kasih, instrumen upacara adat, dan simbol sosial hingga pada hari ini banyak Ulos yang digunakan sebagai bahan pakaian dengan motif yang indah dan menarik.

Ulos terdiri dari jenis, motif, warna hingga fungsi yang berbeda. Sebuah ulos dapat mengandung berbagai informasi terkait nilai budaya. Perbedaaan ini juga dipengaruhi daerah di mana ulos tersebut dibuat. Sebagai contoh, warna dasar Ulos untuk daerah Tapanuli Utara adalah putih, merah dan hitam sedangkan untuk daerah Toba adalah hitam kecokelatan dan keputih-putihan (Dirjen Kebudayaan Indonesia, 2014).

Setelah melaksanakan pengamatan dan pengumpulan informasi selama kurang lebih enam bulan, ditemukan bahwa hingga saat ini, semua informasi itu belum terstruktur dengan baik. Tabel 1 berikut menunjukkan salah satu contoh mengenai perbedaan informasi jenis Ulos pada tiga sumber informasi Ulos.

Tabel 1. Perbandingan Informasi dari Beberapa Sumber

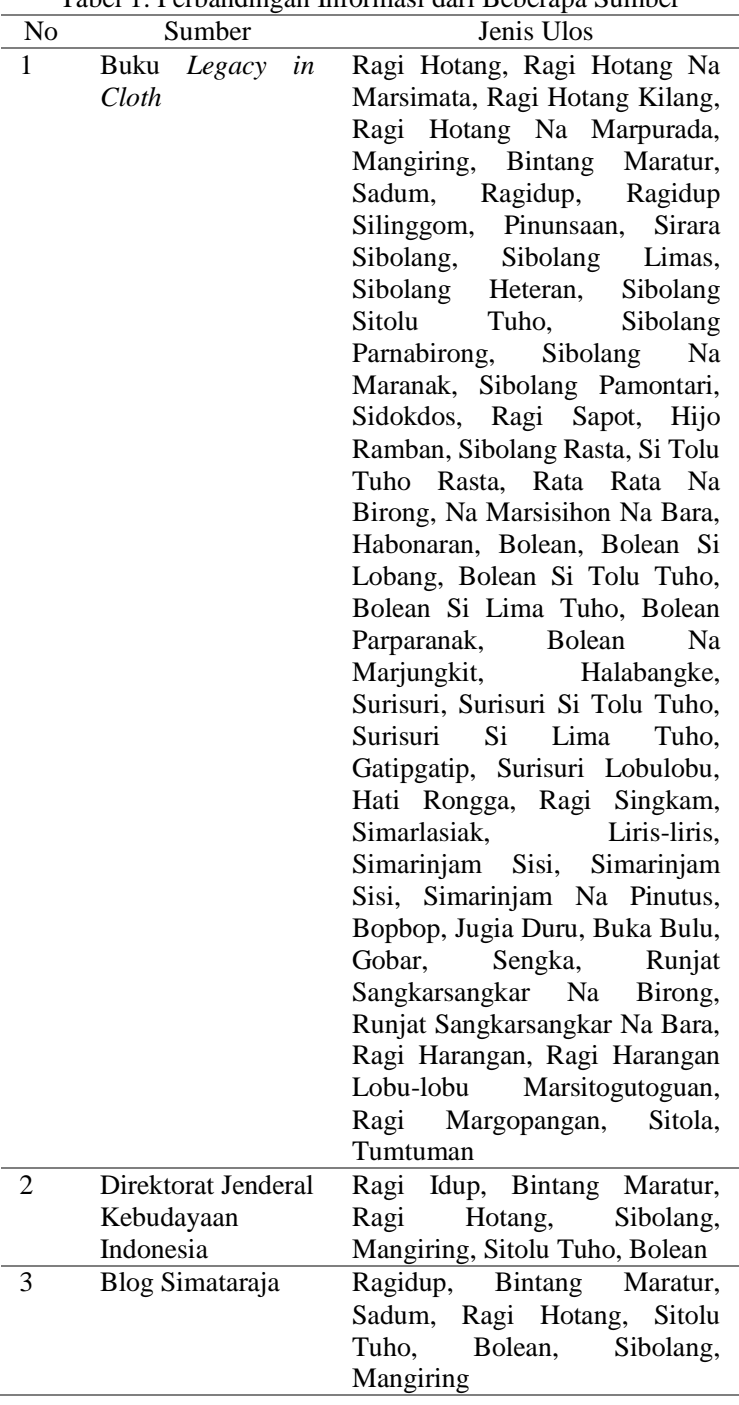

Selain perbedaan dalam hal jumlah jenis ulos, terdapat juga perbedaan informasi yang menimbulkan perbedaan dalam penggunaan Ulos dalam berbagai acara atau kegiatan. Sebagai contoh, dalam sebuah sumber informasi menyatakan bahwa Ulos Sibolang hanya dapat digunakan pada acara kematian dan pernikahan, sementara di sumber lain disebutkan bahwa Ulos Sibolang dapat digunakan juga pada acara syukuran/permohonan kehamilan dan acara baptis. Untuk itu diperlukan data yang terstruktur untuk domain Ulos Batak Toba.

Ontologi menjadi salah satu solusi untuk mengelola data sehingga dapat memberikan informasi yang bernilai semantik (Reyes, Mireya dan Vázquez, 2017). Ontologi merupakan spesifikasi formal dan eksplisit dari sebuah domain. Ontologi mendeskripsikan secara formal berbagai konsep dari sebuah domain dan keterkaitan antar konsep tersebut (Antoniou dan Harmelen, 2004, Oprea, 2015). Ontologi mendeskripsikan konsep dan keterkaitan antar konsep dalam suatu domain secara eksplisit (W3C, 2015; Noy dan Mcguinnes, 2008). Dalam ontologi konsep dari domain saling berkaitan satu sama lain sehingga dapat dilihat sebagai suatu bentuk kesatuan data (linked-data) yang membentuk pola yang terstruktur (Biser, Heath, dan Lee, 2009). Pola yang terstruktur tersebut membantu menghasilkan informasi yang bernilai semantik. Ontologi merupakan mekanisme penalaran yang baik yang berbeda dengan proses pengolahan data pada umumnya seperti penggunaan konsep string match.

Ontologi dapat direpresentasikan menggunakan Web Ontology Language (OWL) dan kemudian menggunakan SPARQL sebagai query language. Ontologi dapat dikembangkan dengan mengikuti beberapa metodologi. Salah satunya adalah metodologi Methontology yaitu metodologi yang dikembangkan dengan mengikuti konsep pemodelan prototyping. Dengan menggunakan pemodelan ini, diharapkan para ahli dalam domain terkait dapat memberikan masukan kepada pengembang ontologi domain tersebut.

Dalam pekerjaan ini dikembangkan ontologi untuk domain Ulos Batak Toba yang direpresentasikan dengan OWL. Dengan metode Methontology, OWL yang dihasilkan dapat menjadi dasar pengembangan ontologi yang lengkap sebagai sebagai referensi utama untuk data Ulos Batak Toba. Penyediaan data yang terstruktur ini akan dapat digunakan untuk menghasilkan informasi yang bernilai semantik yang lebih baik.

\section{METODOLOGI PENELITIAN}

Penelitian ini termasuk ke dalam penelitian pengembangan. Untuk menyediakan sebuah sumber data terstruktur untuk domain Ulos Batak Toba, dikembangkan sebuah ontology dalam bentuk OWL. Dikembangkan juga sebuah simulator untuk mengevaluasi performansi ontologi tersebut dalam menyediakan informasi yang lebih bernilai semantik. 


\subsection{Pengembangan Ontologi}

Pada umumnya proses pembangunan ontologi dilakukan dengan metode iterasi karena konsep pada suatu domain dapat berubah. Rangkaian proses perancangan yang dilakukan di seluruh life cycle ontologi adalah sebagai berikut:

1. Menentukan domain dan batasan dari ontologi yang dikembangkan. Beberapa hal yang perlu diperhatikan dalam menentukan domain dan batasannya adalah tujuan domain dibangun, informasi yang akan disediakan, siapa yang akan mengatur dan memelihara, kepada siapa ontologi ditujukan.

2. Mempertimbangkan penggunaan ontologi yang sudah ada. Penggunaan kembali ontologi dapat dilakukan bila ontologi tersebut memiliki konsep yang sama.

3. Menentukan terminologi dalam sebuah domain.

4. Menentukan kelas dan hirarki kelas. Konsep yang sudah ditentukan diklasifikasi dalam kelas. Kelas tersebut dapat distrukturisasi dalam hierarki kelas baik itu dengan metode top-down, bottom-up atau kombinasinya.

5. Menentukan properti dari kelas (slot). Properti adalah ciri atau informasi mengenai sebuah konsep dalam sebuah domain.

6. Menentukan facet dari sebuah slot. Facet berfungsi untuk mendeksripsikan tipe nilai (slot value type), kardinalitas (slot cardinality) dan domain serta remtamg nilai dari sebuah slot.

7. Menentukan individual. Langkah terakhir yang dilakukan dalam pembangunan ontologi adalah dengan membuat individual dari setiap kelas.

Salah satu metodologi yang digunakan dalam pengembangan ontologi adalah metodologi Methontology. Metodologi ini mendukung konsep formalisasi yang merupakan tujuan dari ontologi itu sendiri. Life cyle pembangunan ontologi pada metodologi ini mengikuti pemodelan prototyping. Methontology juga terdiri dari beberapa aktivitas yang dijelaskan pada Tabel 2 .

Tabel 2. Tahapan Methodology Methontology

\begin{tabular}{|c|c|}
\hline Aktivitas & Deskripsi \\
\hline $\begin{array}{l}\text { Project } \\
\text { Management }\end{array}$ & $\begin{array}{l}\text { a. Planning: identifikasi kebutuhan } \\
\text { pembangunan ontologi dan sumber } \\
\text { daya yang dibutuhkan. } \\
\text { b. Control: memastikan kegiatan } \\
\text { pembangunan dilakukan berdasarkan } \\
\text { perencanaan. } \\
\text { c. Quality assurance: kesesuaian } \\
\text { ontologi yang dibangun dengan } \\
\text { kebutuhan. }\end{array}$ \\
\hline $\begin{array}{l}\text { Development- } \\
\text { oriented }\end{array}$ & \begin{tabular}{ll} 
a. & \multicolumn{2}{l}{ Specification: penentuan tujuan dan } \\
peruntukan ontologi yang dibangun. \\
b. $\begin{array}{l}\text { Conceptualization: } \\
\text { konsep dalam ontologi. }\end{array}$ \\
c. $\begin{array}{l}\text { Formalization: } \\
\text { conceptual menjadi }\end{array}$ \\
$\begin{array}{l}\text { model. } \\
\text { transformasiasiable }\end{array}$ \\
d. $\begin{array}{l}\text { Implementation: } \\
\text { computable model } \\
\text { computational language. }\end{array}$ & transformasi \\
\end{tabular} \\
\hline
\end{tabular}

\begin{tabular}{|c|c|}
\hline Aktivitas & Deskripsi \\
\hline & e. Maintenance: pemeliharaan ontologi. \\
\hline \multirow[t]{5}{*}{ Support } & $\begin{array}{l}\text { anowledge acquisition: pengumpulan } \\
\text { knowledge dari sebuah domain. }\end{array}$ \\
\hline & $\begin{array}{l}\text { b. Evaluation: evaluasi terhadap } \\
\text { ontologi untuk membuat technical } \\
\text { judgment. }\end{array}$ \\
\hline & $\begin{array}{l}\text { Integration: integrasi ontologi dengan } \\
\text { ontologi lain atau aplikasi. }\end{array}$ \\
\hline & $\begin{array}{l}\text { d. Documentation: dokumentasi tiap } \\
\text { tahap pembangunan. }\end{array}$ \\
\hline & $\begin{array}{l}\text { e. Configuration Management: } \\
\text { pengontrolan perubahan ontologi. }\end{array}$ \\
\hline
\end{tabular}

Selanjutnya, tahap yang dilakukan setelah pembangunan ontologi adalah proses evaluasi. Ada banyak metode untuk proses evaluasi ontologi. Hal ini dipengaruhi oleh beranekaragamnya jenis domain, ukuran, tujuan bahkan bahasa yang digunakan untuk membangun ontologi. Metode evaluasi dapat dilakukan secara otomatis pada suatu tool tertentu dengan tidak mengevaluasi taksonomi dan konten (Bilgin, 2014). Salah satu proses evaluasi yang dapat dilakukan adalah dengan menggunakan Protégé dan membangun sebuah simulator. Protégé dilengkapi dengan Reasoner yang berfungsi untuk mengecek konsistensi taksonomi dan konsistensi class, property dan individual dari sebuah ontologi (Stanford University, 2013). Protégé menjadi alat yang paling banyak digunakan untuk pengembangan ontology (Musen, 2015). Sedangkan simulator merupakan metode evaluasi yang dilakukan dengan menggabungkan ontologi dalam sebuah aplikasi di mana ontologi berfungsi sebagai sumber data yang kemudian di-retrieve dengan menggunakan SPARQL (SQL language untuk OWL).

\subsection{Web Ontology Language (OWL)}

OWL merupakan semantic markup language yang digunakan untuk merepresentasikan ontologi. OWL memungkinkan informasi dimengerti oleh mesin. OWL dikembangkan sebagai vocabulary extension dari RDF (W3C, 2004). OWL terdiri dari beberapa komponen berikut:

1. Class (kelas), merupakan kumpulan dari individual dengan karateristik yang sama.

2. Individual (Instance), merupakan komponen ontologi yang menggambarkan objek dalam sebuah domain. Setiap individual harus berada dalam sebuah kelas dan setiap individual yang berada dalam sebuah kelas memiliki karateristik yang sama.

3. Properties, merupakan binary relationship yang menghubungkan individual dengan individual lain. Properties memiliki karateristik sebagai berikut (Horridge, 2011):

- Functional properties, relasi dimana satu individual hanya bisa berhubungan dengan paling banyak satu individual saja.

- Inverse functional properties, relasi yang merupakan inverse dari functional properties.

- Transitive properties, relasi di mana apabila individual $a$ berhubungan dengan 
individual $b$, individual $b$ berhubungan dengan individual $c$ maka individual $a$ dan individual $c$ juga memiliki hubungan.

- Symmetric properties, relasi timbal balik antara dua individual.

- Asymmetric properties, relasi yang tidak bisa timbal balik antara dua individual.

- Irreflexive properties, relasi yang tidak dapat digunakan untuk individual itu sendiri.

\subsection{SPARQL}

SPARQL merupakan bahasa query untuk data RDF. SPARQL memiliki fungsi yang sama dengan query SQL yang digunakan pada basisdata sistem yakni untuk melakukan proses data retrieving.

Berbeda dengan RDBMS, ontologi tidak harus memiliki primary key dan juga foreign key untuk menunjukkan keterhubungan antara satu tabel dengan tabel lain (Sinaga, 2014). Ontologi menggunakan konsep RDF Graph (subject-predicate-object). Beberapa perbedaan antara query SQL pada Relational Database Management System (RDBMS) dengan SPARQL dapat dilihat pada Tabel 3 berikut ini.

Tabel 3. Perbedaan Query SQL dan SPARQL

\begin{tabular}{ll}
\hline \multicolumn{1}{c}{ Query SQL RDBMS } & \multicolumn{1}{c}{ SPARQL } \\
\hline $\begin{array}{l}\text { Mendeklarasikan tabel mana } \\
\text { yang akan digunakan sebagai } \\
\text { sumber data }\end{array}$ & $\begin{array}{l}\text { Mendefinisikan URI sebagai } \\
\text { penunjuk darimana data akan } \\
\text { diambil }\end{array}$ \\
\hline $\begin{array}{l}\text { Data yang akan diambil } \\
\text { didefinisikan dalam query } \\
\text { dengan mencantumkan field } \\
\text { tabel dari mana data akan } \\
\text { diambil }\end{array}$ & $\begin{array}{l}\text { data yang akan diambil } \\
\text { dengan mencantumkan naery } \\
\text { kelas dan dibubuhi tanda "'?" } \\
\text { di depan nama kelas tersebut. }\end{array}$ \\
\hline $\begin{array}{l}\text { Query menggunakan operator } \\
\text { like atau tanda "=" }\end{array}$ & $\begin{array}{l}\text { Query menggunakan operator } \\
\text { regex (contain) dan tanda "=" } \\
\text { (match) }\end{array}$ \\
\hline
\end{tabular}

SPARQL memiliki beberapa keunggulan dalam proses retrieving data yaitu (W3C, 2009):

1. Mampu mengambil nilai dari structured dan semi-structured data.

2. Melakukan querying menggunakan relasi yang tidak dikenal.

3. Mendukung operasi join yang kompleks saat melakukan querying.

4. Mentransformasi data RDF dari sebuah vocabulary.

SPARQL query berisi sekumpulan triple pattern yang disebut dengan Basic Graph Pattern. SPARQL query terdiri dari (W3C, 2009):

1. Pendeklarasian prefix digunakan untuk menunjukkan URI.

2. Pendefinisian dataset untuk menyatakan RDF graph yang akan di-query.

3. Result Clause mendefinisikan informasi yang dihasilkan oleh query yang dibuat.

4. Query Pattern menspesifikasikan apa yang akan di-query berdasarkan dataset.

5. Query Modifiers digunakan untuk menata kembali hasil query (group by, order by)
Bentuk umum sintaks SPARQL dapat dilihat pada potongan kode yang ditunjukkan pada Gambar 1 berikut ini.

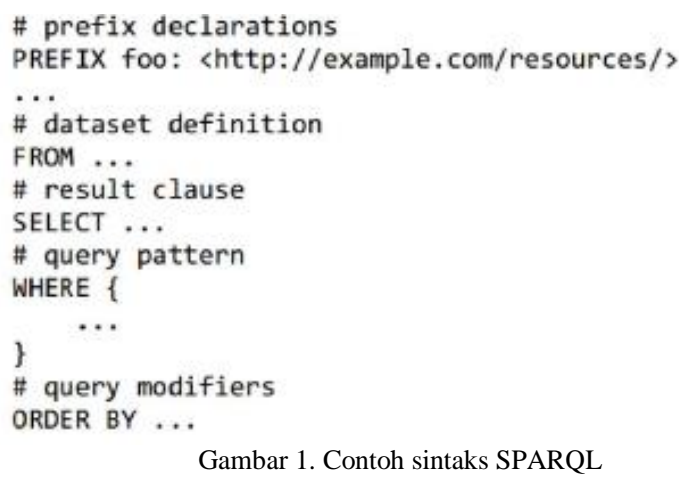

\subsection{Protégé}

Protégé dikembangkan di Stanford University (Stanford University, 2013) yang bersifat open source. Protégé mendukung konstruksi domain ontologi dan juga mengatur data yang dimasukkan dalam sebuah ontologi. Protégé dapat menerima file yang menggunakan bahasa XML, RDF, OWL dan CARIN. Protégé juga mampu mengekspor file ke dalam bentuk XML, RDF/RDFS, OIL, XML Schema, Flogic, CLIPS, Java dan HTML. Protégé dapat diunduh langsung melalui website Stanford University (https://protege.stanford.edu/) (Stanford University, 2013).

Protégé dilengkapi dengan paket visual seperti Ontoviz, EzPal sehingga ontologi dapat divisualisasi dalam bentuk diagram. Keunggulan Protégé dibandingkan dengan berbagai tools pengembang ontologi yang lain adalah bahwa Protégé mendukung tools builder, knowledge engineer dan domain specialist secara bersamaan. Tools lain pada umumnya hanya berfokus pada knowledge engineer sehingga tidak memiliki fleksibilitas untuk melakukan metamodelling.

Pemodelan yang digunakan dalm Protégé adalah pemodelan berbasis knowledge yang terbagi menjadi (Stanford University, 2013):

1. Protégé Frame Editor, pembangunan ontologi dilakukan dalam frame-based dengan menggunakan Open Knowledge Base Connectivity Protocol (OKBC).

2. Protégé OWL, pembangunan ontologi dengan dukungan OWL. Protégé-OWL Application Programming Interface (API) merupakan sebuah Java Library yang open source untuk OWL dan RDF.

Protégé juga dilengkapi dengan Reasoner dengan nama $\mathrm{FaCT}++$ yang berfungsi untuk proses evaluasi ontologi. 


\section{ANALISIS PENERAPAN ONTOLOGI}

\subsection{Deskripsi Domain Studi Kasus: Ulos Batak Toba}

Berdasarkan hasil tinjauan pustaka, diperoleh bahwa dokumentasi terlengkap saat ini mengenai ulos adalah buku karangan Sandra Niessen yang berjudul Legacy in Cloth (Niessen, 2009). Buku ini menjadi sumber utama untuk data yang digunakan karena mengandung banyak konsep domain dari Ulos Batak.

Pendefinisian konsep domain yang dilakukan adalah dengan menerapkan konsep berbasis obyek. Obyek yang memiliki kesamaan karateristik akan dikategorikan ke dalam kelas yang sama. Demikian juga dengan individual dalam ontologi, yang jika memiliki kesamaan karateristik, juga dikategorikan ke dalam kelas yang sama.

Berdasarkan hasil pengamatan terhadap domain Ulos Batak Toba, maka berikut ditentukan domain concept yang dibuat di dalam ontologi:

1. Jenis Ulos

Berbagai jenis Ulos dikelompokkan menjadi satu kelas. Ulos tersebut memiliki karateristik yang sama yaitu memiliki kategori, asal, pengguna, warna, motif, fungsi dan desain. Ilustrasi individual dalam satu kelas dapat dilihat pada Gambar 2.

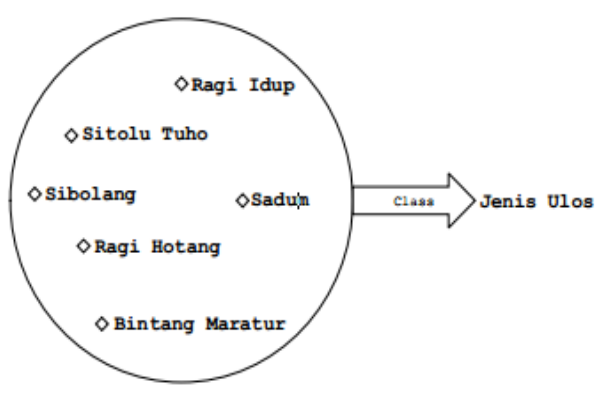

Gambar 2. Kelas Jenis Ulos

Pada Gambar 2 di atas ditunjukkan bahwa dalam kelas Jenis Ulos terdapat individual seperti: Ragi Idup, Sitolu Tuho, Sibolang, Ragi Hotang, Sadum, Bintang Maratur.

2. Kategori Ulos

Setiap Ulos dapat dikelompokkan ke dalam satu kategori. Kategori ini didasarkan oleh penggunaan Ulos tersebut. Sebagai contoh, Ulos Ragi Hotang dan Ragi Idup dikategorikan dalam Ulos Hela karena diberikan kepada menantu laki-laki (Batak: hela).

3. Asal Ulos

Ulos memiliki daerah asal yang berbedabeda, baik itu kecamatan maupun kabupaten. Untuk itu dibuat dua kelas untuk menjelaskan asal Ulos dimana kabupaten merupakan superkelas sedangkan kecamatan merupakan subkelas.

4. Pengguna Ulos (Pemberi dan Penerima Ulos)
Dalam budaya Batak Toba peruntukan Ulos juga diatur sedemikian rupa sehingga setiap Ulos tidak dapat diberikan oleh dan/atau diperuntukkan kepada seseorang secara sembarangan. Pemberi dan penerima Ulos disesuaikan dengan kategori Ulos.

5. Warna Ulos

Setiap jenis Ulos memiliki ciri dari segi warna. Walau dalam satu Ulos terdapat beberapa kombinasi warna dan setiap Ulos memiliki warna dominan.

6. Motif

Motif yang terdapat dalam Ulos tidak hanya berperan sebagai penghias saja tetapi motif tersebut memiliki makna yang berkaitan dengan kehidupan suku Batak Toba. Dalam satu Ulos dimungkinkan ada berbagai macam motif yang ditemukan dimana setiap motifnya memiliki makna yang berbeda.

7. Acara

Ulos tidak digunakan dengan sembarangan tetapi harus mengikuti aturan kapan dan di mana Ulos digunakan. Ulos memiliki peranan tertentu dalam suatu acara adat.

8. Fungsi

Sebagian besar Ulos memang digunakan sebagai selendang, namun beberapa Ulos ada yang secara khusus digunakan sebagai kain gendongan, pakaian, penutup kepala hingga menjadi kain penutup jenazah.

9. Desain Ulos

Pada umumnya, Ulos memiliki desain yang sama yaitu berbentuk persegi panjang dan motif terletak di bagian tengah Ulos. Tetapi ada kalanya terdapat perbedaan desain baik dari segi warna dan motif. Desain umum Ulos dapat dilihat pada Gambar 3.

10. Kamus

Kamus yang dimaksud dalam hal ini adalah istilah Batak Toba yang berkaitan dengan Ulos.

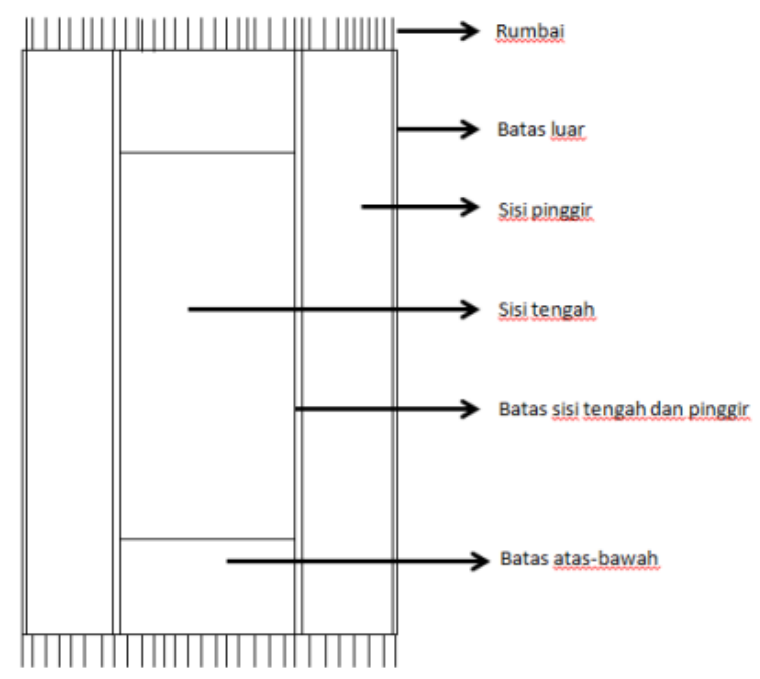

Gambar 3. Desain Umum Ulos 


\subsection{Analisis Pembangunan Ontologi}

Mengikuti proses pada metodologi Methontology, pembangunan ontologi untuk domain Ulos Batak Toba terbagi menjadi tiga aktivitas besar:

1. Project Management

Aktivitas project management terdiri dari perencanaan, kontrol dan quality assurance.

2. Development-Oriented Activities

Aktivitas development-oriented terdiri dari empat aktivitas. Aktivitas pertama adalah penentuan tujuan, batasan dan kepada siapa ontologi ditujukan. Aktivitas kedua yakni pengumpulan konsepdomain. Dalam hal ini sumber utama yang digunakan adalah buku Legacy in Cloth (Niessen, 2015). Aktivitas ketiga adalah transformasi ontologi dari bentuk konsep ke OWL menggunakan Protégé. Aktivitas terakhir adalah pengembangan ontologi.

3. Support

Aktivitas support terdiri dari aktivitas mempelajari domain Ulos Batak Toba; evaluasi dengan Reasoner dan simulator; dokumentasi pengembangan ontologi.

\subsection{Evaluasi Ontologi}

Evaluasi ontologi dilakukan dengan menggunakan dua kegiatan sebagai berikut:

1. Menggunakan Protégé

Protégé dilengkapi dengan Reasoner FaCT++. Reasoner berfungsi untuk memeriksa konsistensi konsep ontologi baik itu kelas, properti dan individual serta tipe data yang digunakan. Apabila ditemukan ketidakkonsistenan dalam desain ontologi, Reasoner menampilkan pesan kesalahan dan memberikan penjelasan kesalahan tersebut.

2. Membuat sebuah simulator

Simulator yang dibangun merupakan sebuah aplikasi berbasis web yang dibangun dengan menggunakan bahasa pemograman Java. Untuk menghubungkan ontologi dengan aplikasi, digunakan teknologi Jena. Simulator yang dibangun merupakan sebuah aplikasi pencarian tentang Ulos Batak Toba. Data ulos di-retrieve menggunakan SPARQL Query dari ontologi yang sudah dibangun.

\section{IMPLEMENTASI ONTOLOGI}

\subsection{Spesifikasi}

Ontology requirement specification untuk Ulos Batak Toba dipaparkan pada Tabel 4.

Tabel 4. Ontology Requirement Specification Ontology Requirement Specification

\begin{tabular}{ll}
\hline Domain & \multicolumn{1}{c}{ Ulos Batak Toba } \\
\hline Purpose & Menyediakan informasi Ulos \\
& Batak Toba yang terstruktur \\
\hline
\end{tabular}

\begin{tabular}{ll}
\hline \multicolumn{1}{c}{ Ontology Requirement Specification } \\
\hline Scope & Memuat informasi mengenai \\
& jenis, kategori, asal, warna dasar, \\
& motif, makna, deskripsi desain, \\
& acara di mana digunakan, fungsi, \\
& pemberi dan penerima Ulos \\
\hline Intended End-User & Suku Batak Toba dan para \\
& pencari informasi Ulos \\
\hline Formalization language & OWL \\
\hline Implementation language & Java \\
\hline
\end{tabular}

\subsection{Conceptualization}

Aktivitas Conceptualization bertujuan untuk mengumpulkan dan mengatur konsep domain dari Ulos Batak Toba. Aktivitas Conceptualization terbagi atas beberapa bagian sebagai berikut:

1. Glossary of Terms

Mengumpulkan semua konsep yang berkaitan dengan Ulos Batak Toba dengan mendaftarkan semua terminologi yang berkaitan dengan domain tersebut.

2. Concept Taxonomies

Melakukan strukturisasi terhadap konsep yang sudah dikumpulkan. Struktur konsep yang digunakan dalam pembangunan ontologi Ulos Batak Toba ini adalah hubungan antara superkelas dan subkelas. Hubungan antara superkelas dan subkelas tersebut dinyatakan dengan relasi is-a seperti yang ditunjukkan pada Gambar 4.

3. Diagram Binary Relation

Diagram ini menunjukkan hubungan antara kelas sumber dengan kelas target seperti yang ditunjukkan pada Gambar 5.

4. Concept Dictionary

Concept Dictionary menggambarkan detail dari sebuah kelas meliputi relasi yang dimiliki dalam suatu kelas, dengan kelas mana saja berelasi, deskripsi singkat bagaimana instance yang dimasukkan ke dalam kelas tersebut.

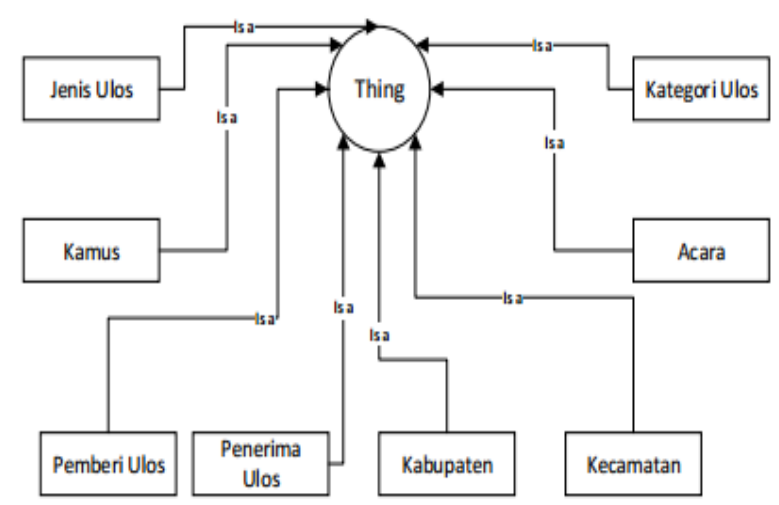

Gambar 4. Concept Taxonomies Ontologi Ulos 


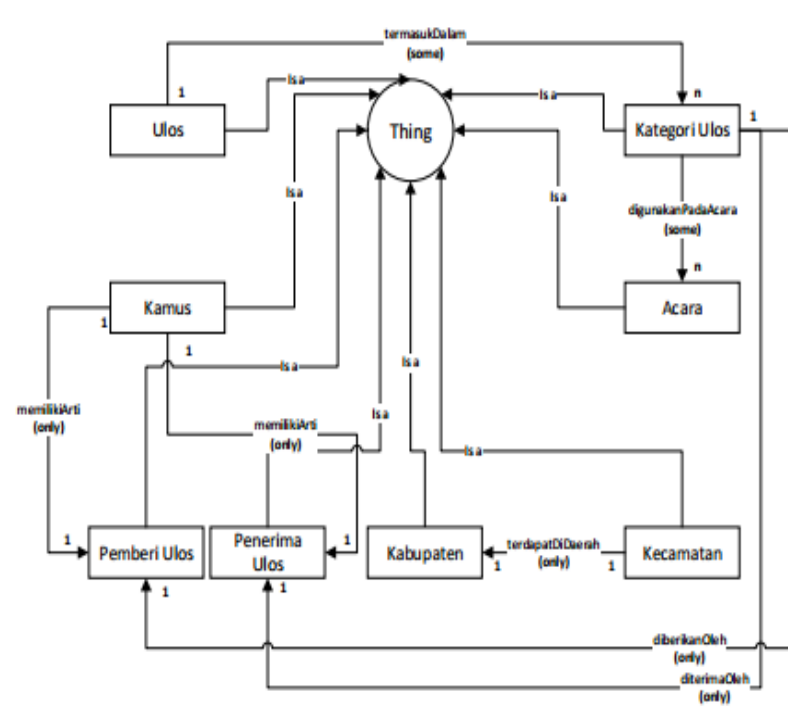

Gambar 5. Diagram Binary Relation

5. Binary Relation

Binary Relation menunjukkan detail dari hubungan antara satu kelas dengan kelas lain meliputi: relasi yang dimiliki, kelas asal, kelas target, dan tipe data yang diperbolehkan.

6. Individual

Pada tahap ini, individual dari setiap kelas harus didefinisikan dengan mengacu pada Concept Dictionary mengenai kriteria individual yang dimaksud.

\subsection{Formalization}

Tahapan Formalization merupakan tahap dimana seluruh konsep ontologi diformalkan dalam language tertentu dalam hal ini mengguankan OWL. Berikut adalaha hasil dari proses Formalization:

1. Kelas

Domain Ulos Batak Toba terdiri dari delapan kelas, yakni Acara, Kabupaten, KategoriUlos, Kecamatan, MaknaKata, Pemberi Ulos, PenerimaUlos dan Ulos.

2. Properti

Terdapat dua jenis properti yang digunakan yaitu object properties dan datatype properties. Terdapat tujuh object properties untuk domain Ulos Batak Toba:
1. berasalDari,
2. diberikanOleh,
3. diterimaOleh,
4. digunakanPadaAcara,
5. memilikiArti,
6. termasukDalam,
7. terdapatDiDaerah.

Sedangkan untuk datatype properties terdapat sebelas properti:

1. berfungsiSebagai,

2. memilikiBatasAtasBawah,
3. memilikiBatasLuar,

4. memilikiBatasSisiTengahDariPing gir,

5. memilikiMakna,

6. memilikiMaknaMotif,

7. memilikiMotif,

8. memilikiRumbai,

9. memilikiSisiPinggir,

10. memilikiSisiTengah,

11. memilikiWarna.

3. Individual

Setiap kelas memiliki individual. Sebagai contoh, kelas Kategori Ulos yang memiliki sebelas individual seperti Ulos Tondi, Ulos Pamintaan, Ulos Pangamai, Ulos Pangambit, Ulos Pangidupi, Ulos Pansamot, Ulos Pansaput, Ulos Parorot, Ulos Saput_ni_saring, Ulos Tomutomu, dan Ulos Tutup_ni_ampang.

\section{EVALUASI ONTOLOGI DAN PEMBAHASAN}

\subsection{Evaluasi Menggunakan Reasoner FaCT++}

Reasoner FaCT++ digunakan untuk memeriksa konsistensi kelas, properti dan individual. Jika ditemukan ketidakkonsistenan pada rancangan OWL, maka Reasoner akan memberikan tanda kesalahan dan memberikan penjelasan terhadap kesalahan tersebut. Salah satu contoh kesalahan yang ditangkap saat pembangunan ontologi menggunakan $\mathrm{FaCT}++$ dapat dilihat pada Gambar 6.

Contoh pada Gambar 6 menunjukkan bahwa terdapat ketidakkonsistenan terkait properti berfungsiSebagai. Properti berfungsiSebagai merupakan object properties yang menghubungkan individual pada kelas Ulos dengan individual pada kelas KategoriUlos. Namun pada OWL yang dievaluasi, properti berfungsiSebagai digunakan sebagai datatype properties yang menghubungkan individual di kelas Ulos dengan nilai data.

\subsection{Evaluasi Menggunakan Simulator}

Simulator yang digunakan merupakan aplikasi berbasis web yang dibangun dengan menggunakan bahasa pemograman Java. Simulator ini dibangun dengan menggunakan teknologi Jena. Jena merupakan framework Java yang menyediakan API yang dapat digunakan untuk mengekstraksi dan menuliskan OWL. Simulator ini merupakan aplikasi pencarian informasi. Cara kerja simulator untuk ontologi Ulos Batak Toba dapat dilihat pada Gambar 7.

Proses get data dilakukan dengan menggunakan SPARQL Query Sebelum memasukkan query ke dalam simulator, SPARQL Query tersebut di-test di Protégé terlebih dahulu. Protégé mendukung eksekusi sintaks SPARQL. Layar kerja untuk eksekusi query dibuka melalui tab SPARQL Query. 


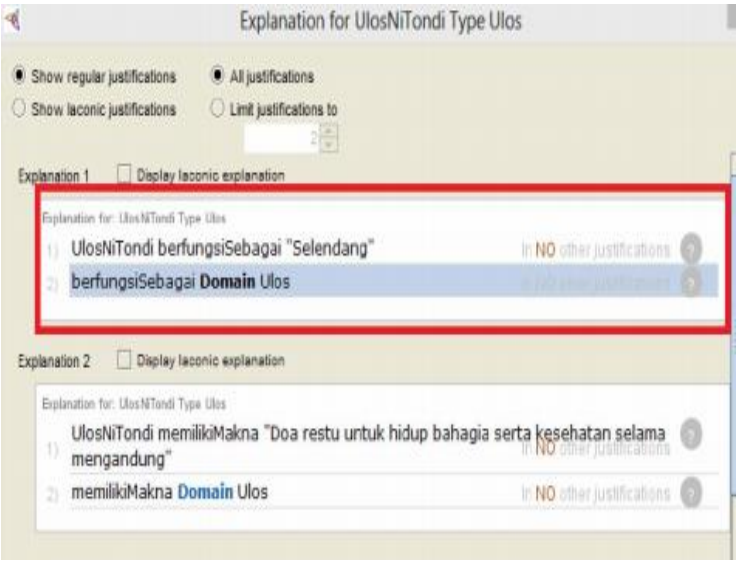

Gambar 6. Evaluasi Menggunakan Reasoner FaCT++

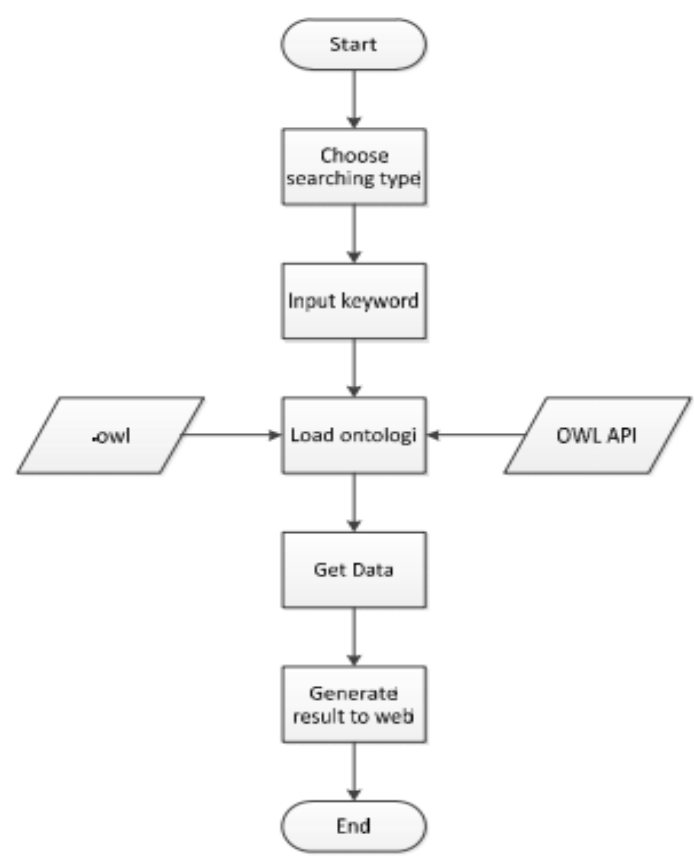

Gambar 7. Cara Kerja Simulator

Berikut adalah beberapa contoh SPARQL Query yang digunakan:

1. Query dengan 2 result clause

Berikut adalah salah satu jenis query dengan 2 result clause yaitu Ulos dan kategori Ulos:

PREFIX rdf: 〈http://www.w3.org/1999/02/22-rdf-syntax-ns\$〉

PREFIX owl: 〈http://www.w3.org/2002/07/owl 》>

PREFIX xsd: 〈http://www.w3.org/2001/XMLSchemał>

PREFIX rdfs: 〈http://www.w3.org/2000/01/rdf-schemał>

PREFIX ulos: 〈http://www.d4ti12.com/Ontologivlos. ow1\#〉

SELECT ?ulos ?kategoriulos

WHERE $\{$ ?ulos ulos:termasukDalam ?kategoriulos

2. Query dengan 2 result clause dan 1 kriteria Berikut digunakan untuk mencari data Ulos yang memiliki warna biru dan hitam:

PREFIX rdf : 〈http://www.w3.org/1999/02/22-rdf-syntax-ns \#〉

PREFIX owl: 〈http://www.w3.org/2002/07/ow1\$〉

PREFIX xsd: 〈http://wWw.w3.org/2001/XMLSchemał〉

PREFIX rdfs: 〈http://www.w3.org/2000/01/rdf-schemał〉

PREFIX ulos: 〈http://www.d4ti12.com/OntologiUlos.ow1\$>

SELECT ?ulos ?warna

WHERE \{ ?ulos ulos:memilikiWarna ?warna.

FILTER regex (?warna, 'Biru tua dan hitam')
3. Query dengan 2 result clause dan menggunakan query modifier

Query berikut digunakan untuk mancari Ulos dan kecamatan dari mana Ulos itu berasal dimana kemudian data yang ditampilkan disusun berurut berdasarkan kecamatan.

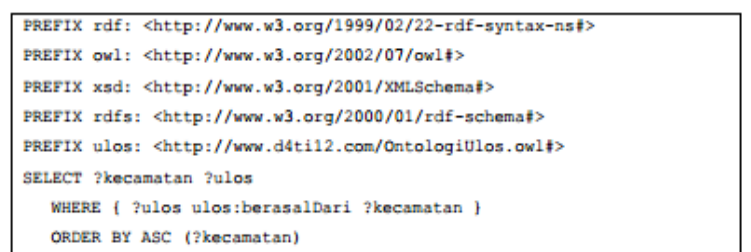

Simulator yang dibangun menyediakan dua jenis pencarian informasi sebagai berikut:

1. Simple Search

Fitur pencarian berdasarkan satu kriteria pencarian seperti yang ditunjukkan pada Gambar 8.

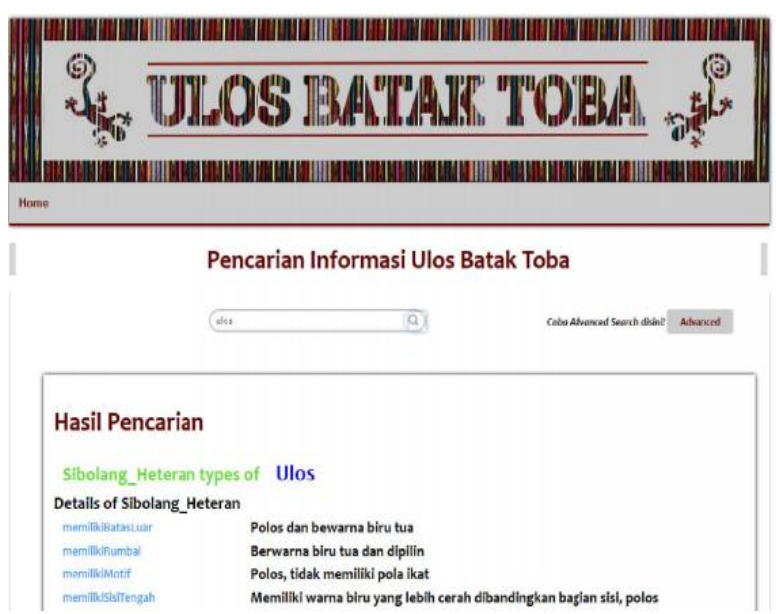

Gambar 8. Simple Search

2. Advance Search

Fitur pencarian yang lebih lengkap yang menerapkan konsep RDF graph statement yaitu <subjek> <predikat> <objek> seperti yang ditunjukkan pada Gambar 9.
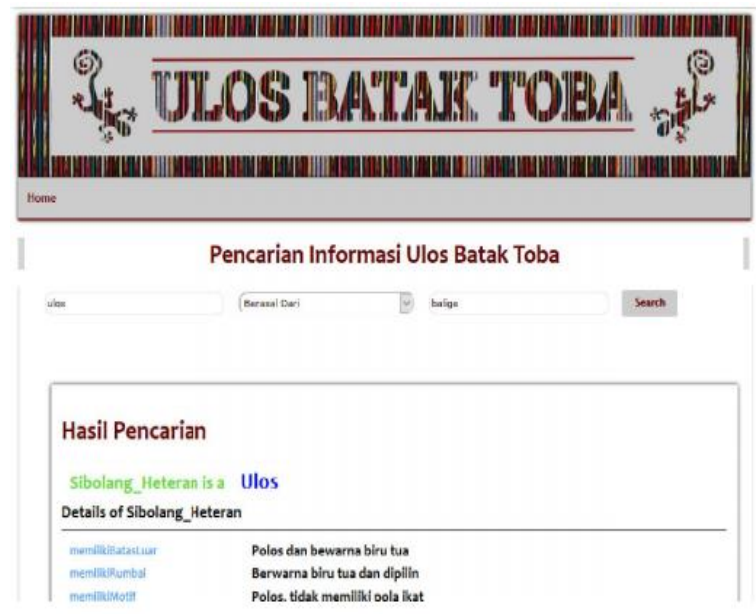

Gambar 9. Advance Search 


\subsection{Pembahasan}

Evaluasi dengan menggunakan Reasoner FaCT++ memberikan kesimpulan bahwa ontologi dibangun sudah memenuhi kriteria konsistensi. Hal ini menujukkan bahwa konsep ontologi OWL untuk Ulos Batak Toba yang dikembangkan konsisten dan tidak terdapat kesalahan. Seluruh komponen kelas, properti, individual dan tipe data tidak mengandung ketidakkonsistenan.

Evaluasi selanjutnya adalah dengan menggunakan simulator dimana untuk proses retrieving data menggunakan SPARQL Query. Salah satu query yang digunakan dalam simulator adalah sebagai berikut:

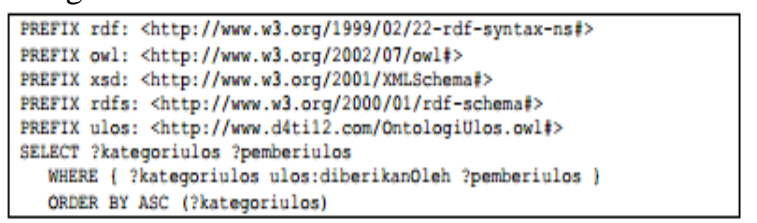

Keterangan:

1. SPARQL query diawali dengan deklarasi PREFIX. PREFIX digunakan untuk mendefinisikan URI yang digunakan pada query. Pada contoh di atas terdapat lima URI yang digunakan.

2. Dalam SPARQL query, URI dapat diberikan inisial sehingga dalam query dapat dengan mudah digunakan, misalnya: URI untuk ontologi Ulos Batak Toba diberi inisial "ulos" sehingga pada query hanya perlu menggunakan kata "ulos" saja.

3. Variabel yang digunakan dalam query dimulai dengan tanda tanya (?)

4. Pencarian data dilakukan dengan mendefinisikan properti yang terhubung dengan data yang dicari.

SPARQL Query kemudian dikombinasikan dengan simulator dalam source code untuk proses retrieving data. Proses pencarian data diharapkan lebih kompleks sehingga menghasilkan hasil yang bernilai semantik. Hal ini didukung dengan struktur data yang saling berhubungan satu sama dengan lain (linked-data). Jadi ontologi mendukung penyediaan data yang akurat. Berikut adalah contoh perbandingan pencarian informasi yang pada umumnya menggunakan konsep string match dengan pencarian informasi menggunakan konsep ontology:

1. String Match Concept

Pencarian dengan menggunakan konsep string match ditunjukkan pada Gambar 10. Pencarian ini dilakukan dengan menggunakan search engine Google. Pada gambar tersebut ditunjukkan bahwa pada saat dimasukkan keyword "ulos dari Balige", maka hasil pencarian yang muncul adalah segala sesuatu yang berhubungan dengan ulos atau balige. Jika dilihat, hasil pencarian pertama justru menampilkan informasi mengenai alamat untuk membeli ulos di Balige. Hal ini tentu sangat berbeda dengan tujuan pencarian melalui keyword tersebut.

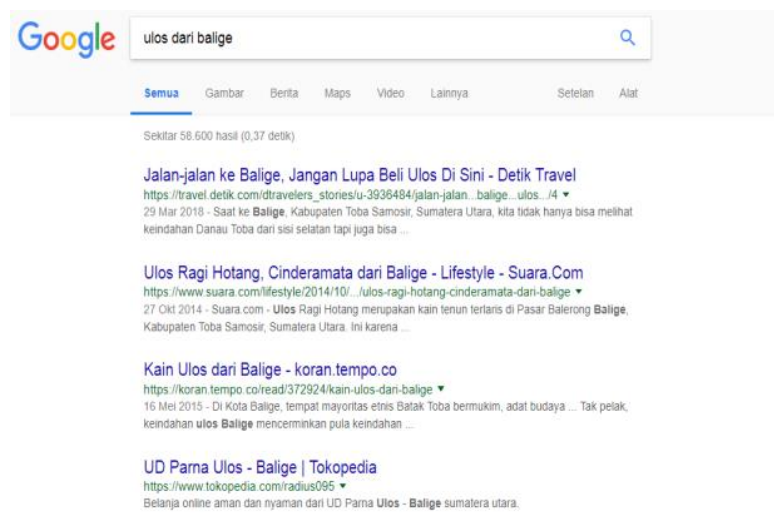

Gambar 10. Hasil Pencarian dengan Konsep String Match

\section{Konsep Ontologi}

Pada Gambar 8 dan Gambar 9 ditunjukkan pencarian dengan menggunakan simulator yang menerapkan konsep ontologi. Pada simulator yang dibangun, keyword pencarian dimasukkan ke dalam 3 text field pencarian (menggambarkan subjekpredikat-objek). Pada simulator dimasukkan keyword, subjek: ulos, predikat: berasal dari, objek: Balige. Kemudian simulator memunculkan Ulos Sibolang beserta informasi rinci mengenai Ulos Sibolang di mana ulos ini merupakan jenis ulos yang berasal dari Balige. Hasil ini tentu lebih akurat dan lebih bermakna secara semantik dibandingkan dengan hasil yang diperoleh pada Gambar 10.

OWL yang sudah dibangun ini tentu masih perlu pengembangan lebih lanjut. Untuk memperbanyak vocabulary di dalam suatu ontologi, sangat dimungkinkan untuk menggabungkan satu ontologi dengan ontologi lain yang memiliki kesamaan vocabulary. OWL menyediakan konsep "owl:import" yang memampukan sebuah web ontology mencakup konsep yang ada pada web ontology lain dengan mengidentifikasi URI dari web ontology yang akan di-import. Namun berkaitan dengan Ulos Batak Toba, sampai dengan saat ini belum ada web ontology yang dibangun. Selanjutnya, diperlukan pengembangan ontologi ini termasuk melalui integrasi dengan web ontology dengan domain Ulos Batak Toba lainnya. Dengan pengembangan dan integrasi antar web ontology maka ontologi akan semakin lengkap sehingga informasi mengenai Ulos Batak Toba yang tersedia lebih lengkap dan terstruktur dengan baik.

Pemanfaatan dokumen digital untuk memperkaya kosakata ontologi ini dapat juga dilakukan pada penelitian selanjutnya. 
Perkembangan teknologi informasi telah menghasilkan berbagai dokumen digital (Ridok dan Indriati, 2015). Kosakata terkait Ulos Batak Toba dapat diperoleh melalui pengolahan kata yang tersedia pada dokumen digital yang membahas terkait Ulos Batak Toba.

\section{KESIMPULAN DAN SARAN}

Dalam penelitian ini telah dilaksanakan pengembangan Web Ontology Language (OWL) pada domain Ulos Batak Toba. Hasil yang diperoleh menunjukkan bahwa domain knowledge untuk Ulos Batak Toba dapat direpresentasikan menggunakan OWL. Ontologi yang dikembangkan dapat membantu menghasilkan informasi yang bernilai semantik. Hal ini didukung karena pola struktur data yang saling berkaitan satu sama lain sehingga ontologi dapat dilihat sebagai kesatuan data (linked-data).

Ontologi dengan domain Ulos Batak Toba dapat dikembangkan selanjutnya dengan menambahkan konsep-konsep yang berhubungan dengan Ulos Batak Toba sehingga ontologi semakin lengkap. Ontologi dengan domain Ulos Batak Toba juga dapat dikembangkan dengan mengintegrasikan beberapa ontologi yang memiliki kesamaan konsep dan memanfaatkan dokumen digital.

\section{DAFTAR PUSTAKA}

ANTONIOU, G. dan HARMELEN, F.V., 2004. A Semantic Web Primer, London: The MIT Press.

BISER, C., HEATH, T. dan LEE, T.B., 2009. Linked Data - The Story So Far. International Journal on Semantic Web and Information Systems, pp. 17-19.

BILGIN, G., DIKMEN, I. dan BIRGONUL, M.T., 2014. Ontology Evaluation: An Example of Delay Analysis. Creative Construction Coneference 2014, Procedia Engineering 85, pp. 61-68.

Dirjen Kebudayaan Indonesia, 2014. Pakaian Adat Sumatera Utara. [online] Tersedia di: <http://kebudayaanindonesia.net/kebudayaa n/1044/pakaian-adat-sumatera-utara.> [Diakses pada Oktober 2015].

HORRIDGE, M., 2011. A Practical Guide To Building OWL Ontologies Using Protege 4 and CO-ODE Tools Edition 1.3, The University Of Manchester, London.

MUHAMMAD, T., 2009. Ulos dan Sejenisnya dalam Budaya Batak di Sumatera Utara: Makna, Fungsi dan Teknologi. Seminar Antarbangsa Tenunan Nusantara, pp. 13-31.

MUSEN, M. A., 2015. The protégé project: a look back and a look forward. AI MATTERS 1, 4 (JUNE 2015), PP. 4-12.
NIESSEN, S., 2009. Legacy in Cloth: Batak Textile of Indonesia, Netherlands: Royal Netherlands Institute of Southeast Asian and Caribbean Studies.

NOY, N.F. dan MCGUINNESS, D.L., 2008. Ontology Development 101: A Guide to Creating Your First Ontology, Stanford University [online]. Tersedia di: <http://protege.stanford.edu/publications/on tology_development/ontology101.pdf.> [Diakses pada Oktober 2015].

OPREA M., 2015. On the Design of a Collaborative Ontology Development Methodology for Educational Systems. In Proceedings of the 7th Balkan Conference on Informatics Conference (BCI '15). ACM, New York, NY, USA, ,pp. 16:1 - 16:7.

REYES, C., TOVAR M., dan VÁZQUEZ, S., 2017. Ontology for the description of a masters degree program in computer sciences. Proceedings of the XVIII International Conference on Human Computer Interaction (Interacción '17). ACM, New York, NY, USA, pp. 12.1 - 12.4.

RIDOK A. dan INDRIATI, 2015, Pengklasifikasian Dokumen Berbahasa Indonesia dengan Pengindeksan Berbasis LSI. Jurnal Teknologi Informasi dan Ilmu Komputer (JTIIK), Vol.2 No. 2, pp. 87-89.

SINAGA, A.M, SIPAHUTAR, R.J., SIAHAAN, J.B.U., dan GULTOM, M.T., 2014. Pengembangan Ontologi pada Semantic Web untuk Proses Purchasing (Studi Kasus: Industri Sepeda) Seminar Sistem Informasi Nasional Indonesia (SESINDO) 2014, Prosiding SESINDO 2014, pp. 227-232.

Stanford University, 2013. A free, Open-Source Ontology Editor and Framework for Building Intelligent System. [online]. Tersedia di: http://www.protege.stanford.edu. [Diakses pada December 2015].

WBC, 2015, Jenis-jenis Ulos Batak Toba. [online] Tersedia di: $<$ http://worldbatakcommunity.blogspot.co m/2015/04/jenis-jenis-ulos-batak-toba.html $>$ [Diakses pada 2 Juli 2017].

W3C, 2015. Ontologies, [online]. Tersedia di: $<$ https://www.w3.org/standards/semanticwe b/ontology.> [Diakses pada Oktober 2015].

W3C, 2004. RDF Primer. [online]. Tersedia di: <http://www.w3.org/TR/2004/REC-rdfprimer-20040210/..> [Diakses pada November 2015].

W3C, 2009. SPARQL By Example. [online]. Tersedia <http://www.w3.org/2009/Talks/0615qbe/.> [Diakses pada Desember 2015]. 